Article

\title{
Public Knowledge of Monarchs and Support for Butterfly Conservation
}

\author{
Jerrod Penn ${ }^{1}$ (1), Hannah Penn ${ }^{2, *(1)}$ and Wuyang $\mathrm{Hu}^{3}$ \\ 1 Department of Agricultural Economics and Agribusiness, Louisiana State University and AgCenter, \\ Baton Rouge, LA 70803, USA; jpenn@agcenter.lsu.edu \\ 2 Department of Entomology, Louisiana State University and AgCenter, Baton Rouge, LA 70803, USA \\ 3 Department of Agricultural Environmental and Economics, The Ohio State University, Columbus, OH 43210, \\ USA; hu.1851@osu.edu \\ * Correspondence: hpenn@agcenter.lsu.edu; Tel.: +1-225-578-1595
}

Received: 8 February 2018; Accepted: 11 March 2018; Published: 14 March 2018

\begin{abstract}
Pollinator populations in North America are in decline, including the iconic monarch butterfly. In order to determine if public knowledge of monarchs informs opinions on butterfly conservation, we surveyed the public to assess their knowledge of monarchs. We also asked participants about their attitudes towards general butterfly conservation and if they believe that butterfly gardens contribute to conservation. Respondents generally had some knowledge of monarchs but were unaware of monarch population declines and the necessity of milkweed to their life cycle. Respondent knowledge was correlated with more positive attitudes about butterfly conservation. Furthermore, membership in an environmental organization increased the likelihood that the participant had prior knowledge of monarchs and cared about monarch conservation. Respondent socioeconomic factors of age and sex were also significantly correlated with conservation attitudes - older and female participants had more positive attitudes towards general butterfly conservation. Interestingly, females were also less likely than males to admit having prior knowledge of monarchs, indicating that gender may also play an important role in conservation outreach efforts. Our study indicates that educational efforts need to be directed more toward individuals not already associated with an environmental organization as these individuals are predisposed to regard conservation positively.
\end{abstract}

Keywords: attitudes; insect identification; milkweed; monarch; outreach; viceroy

\section{Introduction}

Social norms play an integral role in actualizing conservation programs and environmental policies since perceived social norms can alter individuals' conservation decisions. Both Milfont [1] and Primmer and Karppinen [2] showed that perceived norms can impact forester conservation decisions. Similarly, Van Dijk et al. [3] found that farmers consider social expectations when planning conservation management strategies. Social norms and subsequent public opinions can sway the enforcement and funding of conservation-oriented policies through financial appropriations and voting trends [4-6]. For instance, Endangered Species Act policies in the United States [7,8] are more likely to be successful with buy-in from the general public and stakeholders [9-12]. However, general apathy towards conservation, low levels of education on conservation issues, and negative associations with pro-environmental groups have been implicated as potential roadblocks for public and stakeholder support of ESA policies [13-15].

Education or exposure to different values may be an effective way to change the public's opinion on conservation ideas [12,16-19] as attitudes can be based partially on social expectations and narratives [20-22]. For instance, during interviews with immigrant women in Los Angeles, 
Lassister and Wolch [23] found that many times the participants' opinions of marine animal welfare changed after exposure to US norms on animal welfare and treatment. Public outreach efforts, particularly those with hands-on experience, have been particularly useful in this vein [24-28]. García-Cegarra and Pacheco [28] found that whale-watching tour participants stated being more likely to care about marine conservation after taking the tour, and a survey of insect zoo attendees revealed that respondents felt more favorably towards insects after visiting and physically interacting with insects [29]. Furthermore, Suh and Samways [30] show that the public was generally ignorant of the insects rather than "not interested" in their preservation.

The influence of public opinion and policy support is particularly critical for invertebrate (i.e., insects, spiders, etc.) conservation. However, public support for insect communities is generally lacking despite an estimated $\$ 4.5$ billion in economic benefits provided to North America annually [31,32]. Surveys of the Connecticut public and children, revealed a general dislike of insects [16,33]. Additionally, when looking at the valuation placed on invertebrates versus birds, mammals, and even reptiles and fish, invertebrates have been consistently the lowest rated in terms of monetary support for conservation [20,34]. One invertebrate of note is the monarch butterfly (Danaus plexippus L. (Lepidoptera: Nymphalidae)) since it is often used as a teaching device in schools and outreach events due to its iconic orange color and its annual trek across North America [35,36]. Due to this migration, the vast majority of the United States public has the opportunity to interact with this species at some point during the year. However, due to over-wintering site habitat loss as well as the loss and contamination of food resources (milkweed) and habitat in its summer range [37-40], the decline of monarch populations has been of increasing concern [41-43]. Concerns over monarch decline have caused the US Fish and Wildlife to undertake an effort to evaluate its threatened status in accordance with the Endangered Species Act [44-46] in addition to private efforts to conserve and create suitable habitat $[47,48]$. Current recommendations for monarch conservation include the transition of marginal agricultural lands into milkweed plantings, particularly in the northcentral and southern regions of the US including Kentucky where our survey was conducted [49-51]. However, a large amount of stakeholder participation is required, which may require more targeted educational efforts.

Given the overall charisma of monarchs [52] and efforts to change the conservation status of monarchs [53], we aimed to determine if the general public's views on butterfly conservation generally were informed by prior knowledge of monarchs [54,55]. Specifically, we wanted to determine (1) if prior knowledge of monarchs (i.e., appearance, required food sources, and potential decline) affects monarch conservation attitudes. Additionally, we wanted to find the impacts of (2) participation in environmental or garden organizations and (3) socioeconomic factors on both prior knowledge of monarchs and corresponding conservation attitudes. We expected that greater levels of prior knowledge would increase the likelihood of positive attitudes towards butterfly conservation. Furthermore, we expected that participation in environmental and garden organizations would increase both the likelihood of prior knowledge and positive attitudes towards conservation but that environmental organizations would have a greater relative impact compared to gardening groups. Finally, we anticipated that socioeconomic variables would influence participation in environmental or gardening groups, prior knowledge of monarchs, and attitudes towards conservation since data have shown similar trends [56]. The outcomes of our study will inform future education and public outreach needs in order to increase the public's desire for monarch and general insect conservation [57], particularly at a local scale where prior studies have indicated the greatest need [54].

\section{Materials and Methods}

Our main objectives were achieved through a public survey. The study and survey received approval from the Institutional Review Board from the University of Kentucky (Protocol No. 16-0316-X4B), and each respondent acknowledged the terms of participation prior to beginning the survey. We conducted a survey of the public in the Commonwealth of Kentucky over 51 days from 9 May to 22 July 2016 in Fayette County, Kentucky public parks with the approval of 
the University of Kentucky and park managers. Prior to the survey, the questionnaire went through four rounds of focus groups. Each focus group consisted of 5-8 individuals recruited from the University of Kentucky listservs where participants were given the current rendition of the survey and allowed to ask questions and make comments on the clarity and neutrality of the questions. Following focus groups, one pilot study was performed at the UK Arboretum (50 responses) to ensure the accuracy of the information and clarify the content. For the finalized survey, a total of 34 public parks and events were visited at various times throughout the day (approximately 8 a.m.-11 a.m., 3 p.m. -5 p.m., and 6 p.m. -9 p.m.) with some parks sampled repeatedly for special events such as movie nights, outdoor concerts, and sporting events. Although we conducted our survey in and around public parks, we also selected many of these events as being unrelated to conservation in order to reduce potential sampling bias. While on site, potential respondents (any individual passing by) over the age of 18 were able to approach the survey station or were approached by a moderator about taking the survey advertised as related to parks in order to avoid biasing the sample towards only pro-environmental participants [58]. Among observable characteristics, the sample contains a greater proportion of respondents with children and a smaller proportion of more senior respondents compared to the population. While it is difficult to understand the potential direction of the bias in this specific analysis, a meta-analysis by Wiernik et al. [59] showed that age had no effect on environmental awareness or knowledge, and, more broadly, either no or negligible effects across a range of environmental sustainability variables, environmental awareness or knowledge. Although Dupont et al. find that willingness to pay for environmental improvements significantly increases with the presence of children [60], Torgler et al. find no evidence of having children on a range of environmental attitudes [61]. Of course, differences caused by demographic characteristics or other unobservable characteristics of the sample may still affect the results.

Respondents were then given an online survey with an estimated completion time of $10 \mathrm{~min}$ on a tablet device through the platform provided by the research firm Qualtrics (Provo, UT, USA). To single out the effect on conservation attitudes associated with monarchs being a flagship species in addition to its charismatic appearance, each respondent was randomly assigned to a survey about either monarch or viceroy butterflies, a non-threatened, monarch doppelganger (Limenitis archippus L. (Lepidoptera: Nymphalidae)) [62]. The two versions of the survey are identical except for a brief excerpt at the beginning of the survey, each with 40 questions (combination of True-False, multiple choice, and Likert-style). To ensure that respondents were relatively informed, a short excerpt about the corresponding butterfly's food resources and their native range was given followed by three True-False questions about that excerpt. Respondents in the monarch version were also informed that the monarch was under review for the US list of endangered or threatened species as well as its sole reliance on milkweed plants during its larval stage.

The remaining survey questions pertained to prior knowledge of monarchs (stated overall knowledge, food requirements, population decline, and identification), participation in environmental or gardening organizations, prior donations to environmental organizations, extent of outdoor activity, sociodemographic, and attitudes towards butterfly conservation and the use of butterfly gardens for conservation. To quantify each participant's ability to identify a monarch, each respondent was asked to identify a monarch butterfly in two steps. First, they were presented with four sets of paired, similar-looking butterflies (Figure 1A) and asked which set contained the monarch. If they identified the correct pair, they were asked to identify which of the pair was a monarch (Figure 1B), again followed by a question regarding their certainty. In addition, the following Likert questions were asked to estimate prior knowledge:

"Have you ever heard or read about monarch/viceroy butterflies prior to this survey? How much did you know about the decline in monarch populations prior to this survey? How much did you know about the importance of milkweeds to monarch prior to this survey? How important is it to you to help conserve butterfly species? How much do you believe that installing butterfly plants can actually help butterfly conservation?" 


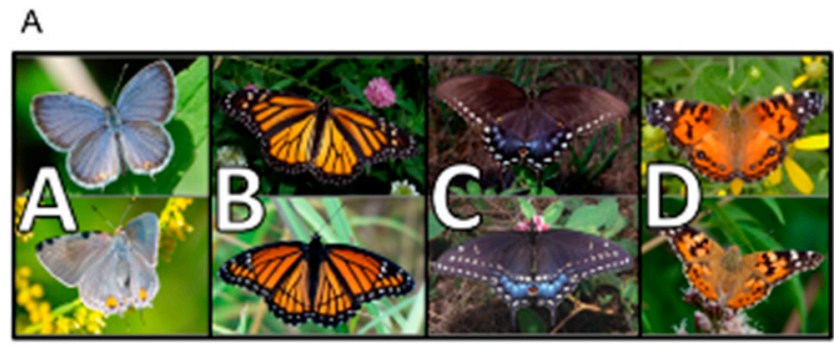

B

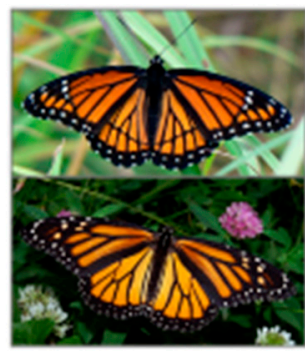

Figure 1. Butterfly identification images used in two steps for (A) identification of the pair with the monarch and viceroy and (B) identification of monarch.

Respondents could choose one of five answers to each of the questions from "not at all" to "a great deal," with the exception of butterfly gardens, which used a slightly different scale (five answers ranging from "not important" to "very important"). In total, 789 participants (Table 1) completed the full survey and were included in the dataset for statistical analyses.

Table 1. Socioeconomic composition of sample versus population estimates $(\mathrm{N}=789)$.

\begin{tabular}{ccc}
\hline Variable & Sample & Lexington-Fayette County ${ }^{1}$ \\
\hline Male & $44.5 \%$ & $49.0 \%$ \\
Female & $55.5 \%$ & $51.0 \%$ \\
Median Age (18 and above) & $39.5 *$ & $42 *$ \\
\hline Age & & \\
$18-24$ & $17.1 \%$ & $18.2 \%$ \\
$25-34$ & $27.4 \%$ & $19.5 \%$ \\
$35-44$ & $23.7 \%$ & $17.2 \%$ \\
$45-54$ & $15.2 \%$ & $15.2 \%$ \\
$55-64$ & $11.4 \%$ & $14.4 \%$ \\
$65+$ & $5.1 \%$ & $15.3 \%$ \\
\hline Education & & \\
High school or less & $21.9 \%$ & $30.4 \%$ \\
Some college or Associate's & $25.6 \%$ & $28.1 \%$ \\
Bachelor's & $27.5 \%$ & $22.6 \%$ \\
Graduate or Professional & $25.0 \%$ & $18.9 \%$ \\
Median Income & $\$ 42,500 *$ & $\$ 51,948$ \\
White & $71.4 \%$ & $75.9 \%$ \\
Black or African American & $14.3 \%$ & $14.4 \%$ \\
Asian & $3.2 \%$ & $3.5 \%$ \\
Other or Multiple Races & $7.1 \%$ & $6.2 \%$ \\
Minor child at home & $46.7 \%$ & $27.2 \%$ \\
Single, never married & $33.1 \%$ & $37.9 \%$ \\
Married & $52.9 \%$ & $43.1 \%$ \\
\hline
\end{tabular}

1 Based on the 2015 American Community Survey 1-year estimates; * Calculated using corresponding category mid-point. 
In order to answer our three questions, the following variables were used as the dependent variables in separate ordered logistic regressions: monarch knowledge, viceroy knowledge, knowledge of monarch declines, knowledge of milkweed importance, ability to identify a monarch, and willingness to conserve butterflies. All models included age, sex, education, income, household with children, race, outdoor recreation, member in a garden club, member of an environmental group, and previous donation to environmental cause as independent variables with the exception of willingness to conserve which had the added variable of monarch knowledge. Because of incomplete responses to these independent variables, the sample used to perform regression analysis (which relies on complete responses) decreases to the results seen in Tables 2 and 3.

All analyses were conducted in Stata 13 (StataCorp LP, College Station, TX, USA) with average marginal effects (MEs) calculated in the same program. MEs are commonly used in the social science discipline representing the change of likelihood of survey respondents be in each of the five possible answer groups (from "not at all" to "a great deal") following one unit of difference between them (e.g., male versus female, or one year older) while holding all other factors unchanged [63]. As an example, if the marginal effect for an independent indicator variable (e.g., female $=1$ ) equals 0.2 for particular level of the dependent variable, this means that the observations with that characteristic (i.e., being a female) are $20 \%$ more likely to have selected that particular level while holding all other factors unchanged. A marginal effect of -0.05 would indicate observations with that characteristic are $5 \%$ less likely to select that level of the dependent variable. Such marginal effects can be generated for every level of the dependent variable, and the sum of all marginal effects for a given independent variable across all levels of the dependent variable must sum to zero. While ME at every level of the responses is generated in the ordered logit models, for brevity, we interpret ME only at the lowest ("not at all" or "not important") and highest ("a great deal" or "very important") extremes of the responses for only those variables that were significant or marginally significant in the corresponding model. 
Table 2. Marginal effects of statistically significant $\left({ }^{*}, p<0.01\right)$ and marginally significant $\left({ }^{\wedge}, p<0.1\right)$ demographic variables on knowledge of monarchs versus viceroys. Blanks cells indicate non-significance.

\begin{tabular}{|c|c|c|c|c|c|c|c|c|c|c|c|}
\hline Viceroy $(n=691)$ & & & & & & Monarch $(n=691)$ & & & & & \\
\hline Variable & 1-Not At All & 2-A Little & 3-Moderate & 4-A Lot & 5-A Great Deal & Variable & 1-Not At All & 2-A Little & 3-Moderate & 4-A Lot & 5-A Great Deal \\
\hline Age & & & & & & Age & & & & & \\
\hline Female* & $11.5 \%$ & $-4.0 \%$ & $-4.1 \%$ & $-2.1 \%$ & $-1.2 \%$ & Female & & & & & \\
\hline Some College & & & & & & Some College * & $-7.4 \%$ & $-5.9 \%$ & $-0.3 \%$ & $4.7 \%$ & $8.9 \%$ \\
\hline Bachelor's^ & $-9.9 \%$ & $3.2 \%$ & $3.7 \%$ & $1.9 \%$ & $1.1 \%$ & Bachelor's* & $-8.0 \%$ & $-6.5 \%$ & $-0.3 \%$ & $5.2 \%$ & $9.5 \%$ \\
\hline Advanced Degree * & $-16.6 \%$ & $4.9 \%$ & $6.3 \%$ & $3.4 \%$ & $2.0 \%$ & Advanced Degree * & $-9.3 \%$ & $-8.3 \%$ & $-0.9 \%$ & $6.4 \%$ & $12.1 \%$ \\
\hline Household Income (\$1000) & & & & & & Household Income (\$1000) & & & & & \\
\hline Minor child & & & & & & Minor child & & & & & \\
\hline Black * & $14.0 \%$ & $-5.8 \%$ & $-4.8 \%$ & $-2.2 \%$ & $-1.2 \%$ & Black * & $12.0 \%$ & $6.5 \%$ & $-3.1 \%$ & $-7.1 \%$ & $-8.3 \%$ \\
\hline Asian & & & & & & Asian $^{\wedge}$ & $9.6 \%$ & $4.9 \%$ & $-2.3 \%$ & $-5.5 \%$ & $-6.7 \%$ \\
\hline Hispanic & & & & & & Hispanic & & & & & \\
\hline Other Race & & & & & & Other Race & & & & & \\
\hline Recreation & & & & & & Recreation & & & & & \\
\hline Garden club & & & & & & Garden club ^ & $-8.8 \%$ & $-9.3 \%$ & $-3.2 \%$ & $5.8 \%$ & $15.5 \%$ \\
\hline Environ. Org.* & $-27.0 \%$ & $5.4 \%$ & $11.3 \%$ & $6.5 \%$ & $3.8 \%$ & Environ. Org. ^ & $-4.9 \%$ & $-4.4 \%$ & $-0.4 \%$ & $3.5 \%$ & $6.2 \%$ \\
\hline Environ. Donation & $-7.1 \%$ & $2.4 \%$ & $2.6 \%$ & $1.3 \%$ & $0.8 \%$ & Environ. Donation * & $-7.8 \%$ & $-7.4 \%$ & $-0.8 \%$ & $6.0 \%$ & $10.0 \%$ \\
\hline
\end{tabular}


Table 3. Marginal effects of statistically significant $\left({ }^{*}, p<0.01\right)$ and marginally significant $\left({ }^{\wedge}, p<0.1\right)$ demographic variables and regression results for all variables on willingness to conserve butterflies. Blanks cells indicate non-significance for marginal effects.

\begin{tabular}{cccccc}
\hline \multicolumn{5}{c}{ Willingness to Conserve $(\boldsymbol{n}=\mathbf{6 9 1})$} \\
\hline \multicolumn{7}{c}{ Marginal Effects } & Model Results \\
\hline Variable & 1-Not At All & 4-A lot & Coef. & Std. Err. & $p$-Values \\
\hline Age * & -0.2 & 0.7 & 0.037 & 0.006 & 0 \\
Female * $_{\text {Some College }}$ & -2.3 & 6.5 & 0.360 & 0.148 & 0.015 \\
Bachelor's & & & -0.312 & 0.225 & 0.166 \\
Advanced Degree & & & -0.044 & 0.224 & 0.843 \\
Household Income (\$1000) & & -0.294 & 0.249 & 0.237 \\
Minor child & & -0.027 & 0.017 & 0.106 \\
Black & & 0.149 & 0.150 & 0.319 \\
Asian & & -0.256 & 0.232 & 0.27 \\
Hispanic & & & 0.124 & 0.442 & 0.779 \\
Other Race & & & -0.132 & 0.385 & 0.731 \\
Recreation & & & 0.166 & 0.296 & 0.574 \\
Garden club & & & 0.038 & 0.036 & 0.293 \\
Environ. Org. & -2.5 & 8.8 & 0.479 & 0.597 & 0.422 \\
Environ. Donation * & -3.5 & 12.8 & 0.458 & 0.246 & 0.062 \\
Monarch Knowledge * & -2.4 & 6.8 & 0.662 & 0.181 & 0 \\
\hline
\end{tabular}

\section{Results}

\subsection{General Attitudes towards Monarch Conservation}

When asked "how important is it to you to help conserve butterfly species," respondents had mixed responses. Very few thought it was "not important" (6.34\%), while the responses among "somewhat important," "important," and "very important" were evenly divided (Figure 2), and the remaining $4.56 \%$ answered "didn't know." This last group is excluded from the logit model. Most individuals also thought that butterfly gardens contributed to butterfly conservation, with $54.5 \%$ thinking that it was "very important" and 35.2\% answering that it was "important."

\section{Respondent Attitudes}

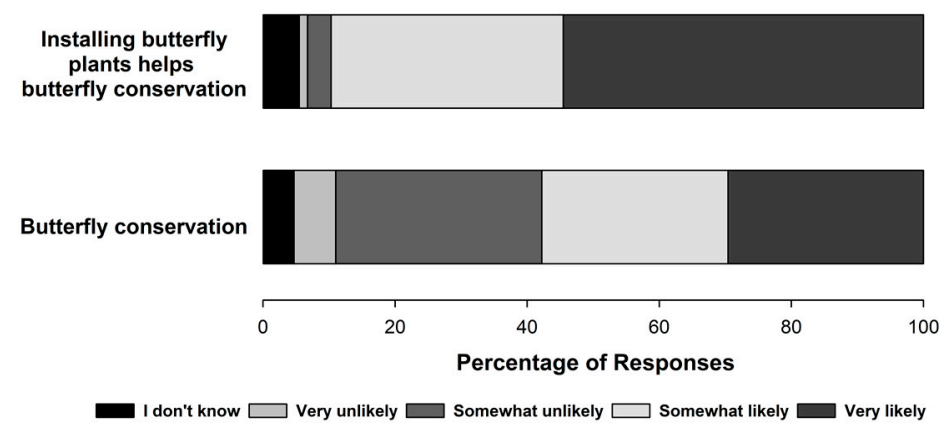

Figure 2. Percentage of responses on a Likert scale regarding participant attitudes on the relative importance of butterfly gardens to butterfly conservation and how much they value butterfly conservation in general.

\subsection{Prior Monarch Knowledge Correlated with Conservation Attitudes}

The general public's reported knowledge about either monarchs or viceroys was lacking, but viceroy knowledge more so (Table 2). When asked about overall prior knowledge, $56.08 \%$ and $16.60 \%$ of participants reported not knowing anything about viceroys and monarchs, respectively (Figure 3). The same trend appears for those who reported knowing "a lot" or "a great deal" about 
viceroys (4.81\% and $2.53 \%$, respectively) and monarchs (19.26\% and $15.84 \%$, respectively). When asked about prior knowledge of monarch population declines, the majority of respondents did not know anything $(40.25 \%)$ or only knew "a little" $(26.58 \%)$. Respondent prior knowledge of the importance of milkweeds as a food resource to monarchs was similar to that of monarch decline. Again, the vast majority of respondents did not know anything (53.67\%) or knew "a little" (15.95\%) about the importance of milkweed (Figure 3).

\section{Respondent Prior Knowledge}

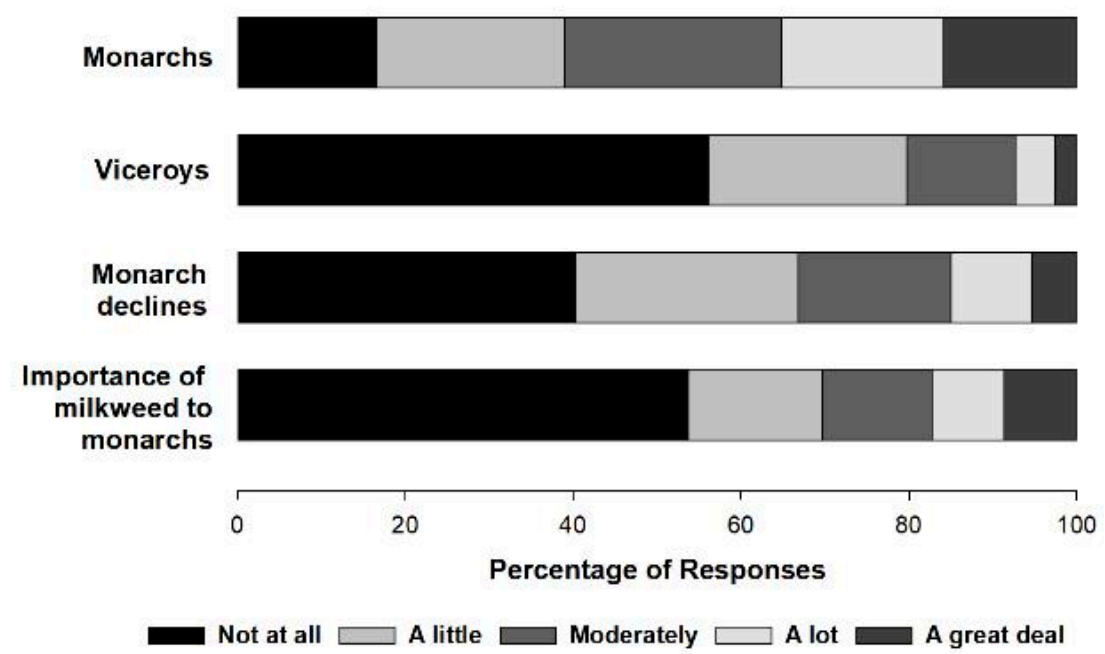

Figure 3. Percentages of responses on a Likert scale for stated prior knowledge of monarch and viceroy butterflies, monarch population decline, and the importance of milkweeds as a food resource for monarch communities.

When given the opportunity to identify a monarch/viceroy pair out of a lineup (Figure 4), most respondents $(78.71 \%)$ could identify the pair correctly. This proportion is significantly different than $25 \%$ (a random guess of an answer out of the four alternatives) $(p<0.01)$. Claiming to have prior knowledge of monarchs $(p<0.01)$, in general, increases the likelihood of a correct answer $(\mathrm{ME}=7.61 \%$; i.e., $7.61 \%$ more likely). However, only $50.89 \%$ of respondents who answered the first identification question correctly could subsequently correctly identify the monarch from the monarch/viceroy pair, $(40.05 \%$ of entire sample), which was not significantly different $(p=0.75)$ from null proportion of $50 \%$ (corresponding to a random guess by respondents as to which butterfly shown is a monarch). This indicates that respondents have a general idea of monarchs' appearance but are not necessarily able to differentiate them from a similar looking species. The only notable predictor of ability to correctly identify a monarch in the second question was stated prior knowledge of monarchs, but only with marginal significance $(p=0.08)$, and the effect was rather small $(\mathrm{ME}=2.88 \%)$. Increases in stated prior monarch knowledge also highly correlated with increased likelihood of respondents finding butterfly conservation "very important" (ME $=6.8 \%$, Table 3 ) and decreased the likelihood of "not important" (ME $=-2.4 \%)$. 


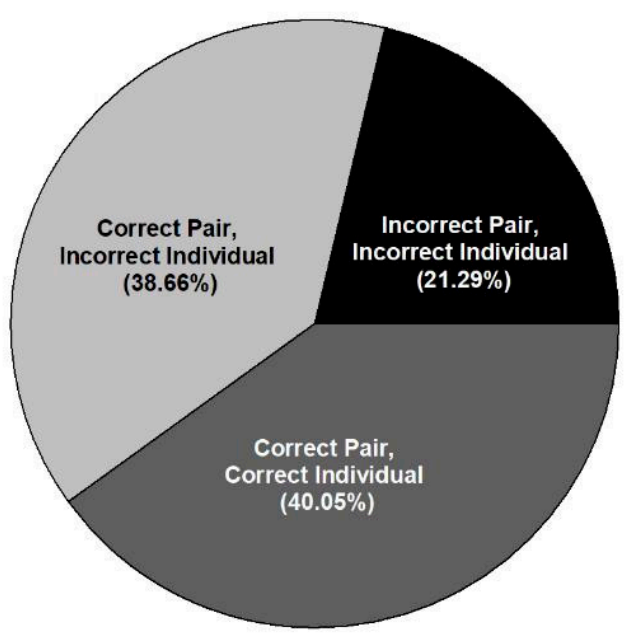

Figure 4. Percentage of respondents who were able to identify the monarch/viceroy pair from Figure 1A and the monarch from the viceroy in Figure 1B.

\subsection{Participation in Environmental Organizations Impacts Prior Knowledge and Attitudes}

Participants that were members of garden clubs $(p=0.01)$, environmental organizations $(p<0.01)$, had previously donated to an environmental group $(p<0.01)$ were more likely to have prior knowledge of monarchs and their decline (Table 2). Such participation increased the likelihood that the respondents knew "a great deal" about monarchs and decreased the likelihood that they know nothing at all. The same trend was true for stated knowledge of monarch declines-being part of a garden club or environmental organization decreased the chance of reporting being "not at all" familiar $(\mathrm{ME}=-23.49 \%,-15.16 \%$, respectively) and increased the chance that respondents knew "a great deal" ( $\mathrm{ME}=10.29 \%, 4.25 \%$, respectively). Respondents who donated to an environmental cause $(p<0.01)$ had a similar association to knowledge of monarch declines (ME "not at all" $=-17.68 \%$; ME "a great deal" $=4.33 \%$ ). Furthermore, those who spent more time outdoors for recreation are also slightly more likely to be aware of monarch declines $(p=0.02)$, with one additional day of recreation per week corresponding to a smaller chance of being not familiar $(\mathrm{ME}=-1.73 \%)$ and a greater chance of knowing "a great deal" $(\mathrm{ME}=0.37 \%)$.

Prior knowledge of milkweed's importance and ability to identify a monarch was less straight-forward. Being an environmental organization member $(p<0.01$, ME "not at all" $=-20.43 \%$, $\mathrm{ME}$ "a great deal" $=8.64 \%)$ or having donated to environmental causes $(p<0.01$, $\mathrm{ME}$ "not at all" $=-11.47 \%, \mathrm{ME}$ "a great deal" $=4.05 \%$ ) increased the likelihood that the respondent knew about the importance of milkweeds as food resources for monarchs, but being a member of a garden club did not impact prior knowledge of milkweed importance $(p=0.12)$. Those who did more outdoor recreation had some evidence of milkweed knowledge $(p=0.06)$ since they were less likely to answer "not at all" $(\mathrm{ME}=-1.5 \%)$ and more likely to answer "a great deal" $(\mathrm{ME}=0.5 \%)$. Association with garden $(p=0.43)$ or environmental organizations $(p=0.53)$, having made a donation to an environmental cause ( $p=0.93)$, or having prior knowledge of viceroys $(p=0.27)$ did not have a significant impact on the ability to find the monarch/viceroy pair.

When asked about monarch conservation, participation in environmental organizations diverged from those who participated in outdoor recreation or in garden clubs (Table 3). Members of environmental organizations $(p=0.06)$ and those who had donated to environmental causes $(p<0.01)$ were more likely to find butterfly conservation "very important" (ME $=8.8 \%$ and $12.8 \%$, respectively). However, members of garden clubs $(p=0.42)$ and those with greater levels of outdoor recreation $(p=0.29)$ were no more likely to find butterfly conservation important. 


\subsection{Socioeconomic Factors Influence Knowledge and Attitudes}

Older participants were more likely to know about monarch declines but the marginal effects were often very low. For instance, the marginal effect for one year older in age $(p=0.03)$ on answering knowing about monarch declines with "not at all" is $-0.03 \%$. This means that all else equal, a person who is one year older than another is $0.03 \%$ less likely to answer "not at all." Conversely, the marginal effect of age is $0.06 \%$ in reporting "a great deal" of knowledge of monarch declines. Age was not a significant predictor of prior knowledge of monarchs $(p=0.84)$ or viceroys $(p=0.09)$ in general or milkweed importance $(p=0.16)$. However, older participants were more likely to find butterfly conservation "very important" $(p<0.01, \mathrm{ME}=0.7 \%)$.

Participant sex was only a significant predictor variable in regressions for prior viceroy knowledge and the importance of butterfly conservation. Females were significantly more likely than males to state that they know about viceroys "not at all" $(p<0.01, \mathrm{ME}=12.70 \%)$ in general but not monarchs $(p=0.90)$. Sex had no impact on state knowledge of monarch declines $(p=0.18)$ or importance of milkweed $(p=0.87)$. Males had greater self-reported knowledge of monarchs and especially viceroys, but males were no more likely to correctly identify the monarch/viceroy pair or monarch butterfly specifically compared to females. For the importance of butterfly conservation, sex was an important predictor $(p=0.01$, Table 3$)$. Females were more likely than males to state that conservation is "very important" $(\mathrm{ME}=7.47 \%)$ and less likely to state that is was "not important" $(\mathrm{ME}=-2.01 \%)$.

Race was correlated with all aspects of prior knowledge and willingness to conserve butterflies. Individuals who self-identified as black were more likely than white individuals to not know about ("not at all") viceroys $(p<0.01, \mathrm{ME}=16.10 \%)$, monarchs $(p<0.01, \mathrm{ME}=11.56 \%)$, monarch declines $(p<0.01, \mathrm{ME}=15.30 \%)$, and the importance of milkweed $(p<0.01, \mathrm{ME}=16.50 \%)$. No other races were significant predictors in these models. Interestingly, Asian $(p=0.07, \mathrm{ME}=-16.07 \%)$ and Hispanic $(p=0.08, \mathrm{ME}=-14.27 \%)$ respondents were significantly less likely to correctly identify monarchs correctly than were white respondents. Whereas, black respondents were no more likely to correctly identify the monarch than white respondents $(p=0.14)$. However, race-related predictors for willingness to conserve butterflies was more similar to those for prior knowledge (Table 3)—black participants $(p=0.04)$ were less likely to find it "very important" $(\mathrm{ME}=-8.81 \%)$ and more likely to find it "not important" (ME $=2.91 \%)$.

Other socioeconomic factors were less important in all regressions. For both general viceroy and monarch knowledge, greater education indicated a smaller likelihood of knowing "nothing" (Table 2). The same trend was true for knowledge of monarch declines $(p<0.01)$ and the importance of milkweed $(p<0.01)$. In both of these cases the marginal effects were stronger for knowing nothing ( $\mathrm{ME}=-5.36 \%$ and $\mathrm{ME}=-5.76 \%$, respectively) versus knowing a great deal $(\mathrm{ME}=0.86 \%$ and $\mathrm{ME}=1.56 \%$, respectively). Respondent education levels did not impact their ability to identify monarchs $(p=0.30)$ or willingness to conserve butterflies (Table 3). Neither being in a household with children nor household income ( $p$-values listed in same order) had an impact on prior knowledge of viceroys (Table 2$)$, monarchs, monarch declines $(p=0.36, p=0.14)$, milkweed importance $(p=0.24$, $p=0.46)$ or monarch identification $(p=0.66, p=0.39)$ and willingness to conserve butterflies (Table 3 ).

\section{Discussion}

Generally, the surveyed respondents stated that they had prior knowledge (from "moderate" to "a lot") of monarchs but had less knowledge of monarch declines and the importance of milkweed to the monarch life cycle (Figure 2). More people claimed knowledge of monarchs than viceroys, interesting as the state butterfly of Kentucky is, in fact, a viceroy and featured on select state license plates [64]. This interest in monarchs compared to viceroys is unsurprising given recent media coverage of monarchs in relation to other topics such as agriculture biotechnology, climate change, and gardening [65-68]. Stated prior knowledge of monarchs was correlated with both being able to identify monarchs and in willingness to conserve butterflies (concern for wildlife), which corroborates 
what prior studies have found $[29,69,70]$ and lends urgency to education efforts to gain public buy-in for milkweed plantings $[49,51,66]$.

Association with environmental groups, including having donated to an environmental cause, increased both the likelihood of monarch knowledge and positive attitudes about butterfly conservation. Participation in garden clubs also increased knowledge but did not correlate with positive attitudes about butterfly conservation, while outdoor recreation and its potential for exposure to monarch did correlate with either. The social values of environmental group members for efforts to save endangered species possibly influenced their support for monarch conservation efforts [71,72], while the garden club members did not hold these same values. In terms of conservation, increased environmental group membership might foment an increased acceptance of environmentally friendly attitudes and behaviors [73-75].

As prior studies have found, environmentally friendly behaviors and attitudes are not predicated on personal values alone as signaled by environmental group membership, but also by demographic and cultural factors [76]. Similarly, we found that even after taking into consideration prior knowledge of monarch and membership in environmental groups, some demographic factors played an integral role in explaining attitudes towards butterfly conservation. We found that an increase in age correlated with an increase in positive attitudes towards conservation as have some other studies [77] though, in contrast to prior studies, higher household income (that tends to increase with age) did not [78,79]. However, the marginal effects of sex were prominent, with self-identified females exhibiting more positive attitudes towards butterfly conservation than did males despite having lower reported levels of monarch knowledge. Since this is a trend seen in prior studies on environmental attitudes and environmentally friendly behaviors, sex clearly has a large impact on conservation strategies in addition to educational efforts to improve public knowledge [79-85].

Since it is difficult to explain the sex differences in conservation attitudes, the results of our study emphasize the need for public education and recruitment to environmental organizations $[69,86,87]$. In terms of educational goals, if increasing public awareness is done in order to increase interest in conservation practices, it appears that more emphasis on specific conservation needs and methods is required (i.e., planting milkweeds and other nectar plants) [88-90]. Future education and outreach efforts for monarch conservation should also target individuals who are not already members of environmental organizations as this group is already inclined to support butterfly conservation. This is especially important as monarch habitat is dependent in large part on private landowners (often farmers), who are likely not members of environmental organizations [91,92]. But previous studies have shown that increased education increased the likelihood of farmers perceiving and mitigating environmental concerns such as monarch habitat loss [93-95].

\section{Conclusions}

Conservation is not a one-sided task. Our study shows that educating the public involves more than the appearance of an animal species, particularly for insects. As there has been little research conducted on social understanding and perception toward conservation or protection of insect species, our analysis adds to this limited depository [52,62]. Based on our work, further studies can examine how individuals may be willing to contribute to protecting the entire range of monarch butterflies including Mexico and Canada or how the public may view the tradeoff between preserving milkweed versus land management such as agricultural weed control [38]. Our research strengthened the idea that identifying public attitudes related to conservation is necessary to determine what aspects of conservation are important to the general public [96].

Acknowledgments: The authors would like to thank the Michael Lorton from the City of Lexington Parks and Recreation Department for permitting surveys at various events and locations and the University of Kentucky Student Sustainability Council for funding. The authors would also to thank those who helped implement the survey (William Fox, Rachel Hart, Jessica Richards, Erica Rogers, and Jason Simon) and the many others we fail to recognize by name but have nonetheless contributed. Artwork credits: butterfly images are all publicly 
available, with credit given to Benny Mazur, Kenneth Dwain Harrelson, Andrew C, John Flannery, Patrick Coin, and Jörg Hempel. Publication of this work was supported by the LSU Open Access Author Fund.

Author Contributions: The following statements should be used J.P. and W.H. conceived and designed the experiments; J.P. performed the experiments; J.P. and W.H. analyzed the data; H.P. wrote and revised the paper.

Conflicts of Interest: The authors declare no conflict of interest. The founding sponsors had no role in the design of the study; in the collection, analyses, or interpretation of data; in the writing of the manuscript, and in the decision to publish the results.

\section{References}

1. Milfont, T.; Mastrangelo, M.E.; Laterra, P.; Gavin, M.C.; Linklater, W.L.; Milfont, T.L. Psycho-social factors influencing forest conservation intentions on the agricultural frontier. Conserv. Lett. 2014, 7, 103-110.

2. Primmer, E.; Karppinen, H. Professional judgment in non-industrial private forestry: Forester attitudes and social norms influencing biodiversity conservation. For. Policy Econ. 2010, 12, 136-146. [CrossRef]

3. Van Dijk, J.; de Snoo, G.; Lokhorst, A.M.; Staats, H.; van Dijk, E.; de Snoo, G.; van Dijk, J. What's in it for me? Motivational differences between farmers' subsidised and non-subsidised conservation practices. Appl. Psychol. 2011, 60, 337-353.

4. Gill, J.D.; Crosby, L.A.; Taylor, J.R. Ecological concern, attitudes, and social norms in voting behavior. Public Opin. Q. 1986, 50, 537-554. [CrossRef]

5. Loomis, J.B.; White, D.S. Economic benefits of rare and endangered species: Summary and meta-analysis. Ecol. Econ. 1996, 18, 197-206. [CrossRef]

6. Moon, W.; Balasubramanian, S.K. Public attitudes toward agrobiotechnology: The mediating role of risk perceptions on the impact of trust, awareness, and outrage. Rev. Agric. Econ. 2004, 26, 186-208. [CrossRef]

7. U.S. Fish and Wildlife Service. Endangered Species Act of 1973; U.S. Fish and Wildlife Service: Washington, DC, USA, 1973.

8. Brown, G.M.; Shogren, J.F. Economics of the Endangered Species Act. J. Econ. Perspect. 1998, 12, 3-20.

9. Lomax, G.P. From breeder reactors to butterflies: Risk, culture, and biotechnology. Risk Anal. 2000, 20, 747-754. [CrossRef] [PubMed]

10. Wolt, J.D.; Peterson, R.K. Agricultural biotechnology and societal decision-making: The role of risk analysis. AgBioForum 2000, 3, 39-46.

11. Missrie, M.; Nelson, K. Direct payments for conservation: Lessons from the monarch butterfly conservation fund. Economics 2005, 88, 339-353.

12. Henle, K.; Alard, D.; Clitherow, J.; Cobb, P.; Firbank, L.; Kull, T.; McCracken, D.; Moritz, R.F.A.; Niemelä, J.; Rebane, M.; et al. Identifying and managing the conflicts between agriculture and biodiversity conservation in Europe-A review. Agric. Ecosyst. Environ. 2008, 124, 60-71. [CrossRef]

13. Kotchen, M.J.; Reiling, S.D. Environmental attitudes, motivations, and contingent valuation of nonuse values: A case study involving endangered species. Ecol. Econ. 2000, 32, 93-107. [CrossRef]

14. Brook, A.; Zint, M.; De Young, R. Landowners' responses to an Endangered Species Act listing and implications for encouraging conservation. Conserv. Biol. 2003, 17, 1638-1649. [CrossRef]

15. Stanley, D.L. Local perception of public goods: Recent assessments of willingness-to-pay for endangered species. Contemp. Econ. Policy 2005, 23, 165-179. [CrossRef]

16. Kellert, S.R. Values and perceptions of invertebrates. Conserv. Biol. 1993, 7, 845-855. [CrossRef]

17. Fulton, D.C.; Manfredo, M.J.; Lipscomb, J. Wildlife value orientations: A conceptual and measurement approach. Hum. Dimens. Wildl. 1996, 1, 24-47. [CrossRef]

18. Herzon, I.; Mikk, M. Farmers' perceptions of biodiversity and their willingness to enhance it through agri-environment schemes: A comparative study from Estonia and Finland. J. Nat. Conserv. 2007, 15, 10-25. [CrossRef]

19. Lucey, A.; Barton, S. Public perception and sustainable roadside vegetation management strategies. Transp. Res. Rec. J. Transp. Res. Board 2010, 2262, 1-15. [CrossRef]

20. Czech, B.; Krausman, P.R.; Borkhataria, R. Social construction, political power, and the allocation of benefits to endangered species. Conserv. Biol. 1998, 12, 1103-1112. [CrossRef]

21. Kubiatko, M.; Prokop, P.; Fancovicova, J.; Kubiatko, M. Vampires are still alive: Slovakian students' attitudes toward bats. Anthrozoos 2009, 22, 19-30. 
22. Dickman, A.J. Complexities of conflict: The importance of considering social factors for effectively resolving human-wildlife conflict. Anim. Conserv. 2010, 13, 458-466. [CrossRef]

23. Lassister, U.; Wolch, J.R. Sociocultural aspects of attitudes toward marine animals: A focus group analysis. Calif. Geogr. 2002, 42, 1-24.

24. Hostetler, M.; Drake, D. Conservation subdivisions: A wildlife perspective. Landsc. Urban Plan. 2009, 90, 95-101. [CrossRef]

25. Müller, M.; Job, H. Managing natural disturbance in protected areas: Tourists' attitude towards the bark beetle in a German national park. Biol. Conserv. 2009, 142, 375-383. [CrossRef]

26. Hostetler, M.; Allen, W.; Meurk, C. Conserving urban biodiversity? Creating green infrastructure is only the first step. Landsc. Urban Plan. 2011, 100, 369-371. [CrossRef]

27. Takahashi, B.; Duan, R.; Witsen, A. Hispanics' behavioral intentions toward energy conservation: The role of sociodemographic, informational, and attitudinal variables. Soc. Sci. Q. 2017. [CrossRef]

28. García-Cegarra, A.M.; Pacheco, A.S. Whale-watching trips in Peru lead to increases in tourist knowledge, pro-conservation intentions and tourist concern for the impacts of whale-watching on humpback whales. Aquat. Conserv. Mar. Freshw. Ecosyst. 2017, 27, 1011-1020. [CrossRef]

29. Pitt, D.; Shockley, M. Don't fear the creeper: Do entomology outreach events influence how the public perceives and values insects and arachnids? Am. Entomol. 2014, 60, 97-100. [CrossRef]

30. Suh, A.N.; Samways, M.J. Development of a dragonfly awareness trail in an African botanical garden. Biol. Conserv. 2001, 100, 345-353. [CrossRef]

31. Losey, J.E.; Vaughan, M. The economic value of ecological services provided by insects. Bioscience 2006, 56, 311-323. [CrossRef]

32. Lemelin, R.H. To bee or not to bee: Whether tis nobler to revere or to revile those six-legged creatures during one's leisure. Leis. Stud. 2013, 32, 153-171. [CrossRef]

33. Snaddon, J.L.; Turner, E.C.; Foster, W.A. Children's perceptions of rainforest biodiversity: Which animals have the lion's share of environmental awareness? PLoS ONE 2008, 3, e2579. [CrossRef] [PubMed]

34. Coursey, D.L. Revealed demand for a public good: Evidence from endangered and threatened species. N. Y. Univ. Environ. Law J. 1997, 6, 411-449.

35. Oberhauser, K.S.; Solensky, M.J. Monarch Butterfly: Biology E Conservation; Oberhauser, K.S., Ed.; Cornell University Press: Ithaca, NY, USA, 2004.

36. Howard, E.; Davis, A.K. The fall migration flyways of monarch butterflies in eastern North America revealed by citizen scientists. J. Insect Conserv. 2009, 13, 279-286. [CrossRef]

37. Honey-Roses, J.; Lopez-Garcia, J.; Rendon-Salinas, E.; Peralta-Higuera, A.; Galindo-Leal, C. To pay or not to pay? Monitoring performance and enforcing conditionality when paying for forest conservation in Mexico. Environ. Conserv. 2009, 36, 120-128. [CrossRef]

38. Pleasants, J.M.; Oberhauser, K.S. Milkweed loss in agricultural fields because of herbicide use: Effect on the monarch butterfly population. Insect Conserv. Divers. 2013, 6, 135-144. [CrossRef]

39. Krischik, V.; Rogers, M.; Gupta, G.; Varshney, A. Soil-applied imidacloprid translocates to ornamental flowers and reduces survival of adult Coleomegilla maculata, Harmonia axyridis, and Hippodamia convergens lady beetles, and larval Danaus plexippus and Vanessa cardui butterflies. PLoS ONE 2015, 10, e0119133. [CrossRef] [PubMed]

40. Pecenka, J.R.; Lundgren, J.G. Non-target effects of clothianidin on monarch butterflies. Sci. Nat. 2015, 102, 1-4. [CrossRef]

41. Malcolm, S.B. Monarch butterfly migration in North America: Controversy and conservation. Trends Ecol. Evol. 1987, 2, 135-138. [CrossRef]

42. Prysby, M.D.; Oberhauser, K.S. Temporal and geographic variation in monarch densities: Citizen scientists document monarch population patterns. In The Monarch Butterfly: Biology and Conservation; Oberhauser, K.S., Solensky, M.J., Eds.; Cornell Press: Ithaca, NY, USA, 2004; pp. 9-20.

43. Inamine, H.; Ellner, S.P.; Springer, J.P.; Agrawal, A.A. Linking the continental migratory cycle of the monarch butterfly to understand its population decline. Oikos 2016, 125, 1081-1091. [CrossRef]

44. Kauffman, V. Service Initiates Status Review of Monarch Butterfly under the Endangered Species Act; U.S. Fish \& Wildlife Service: Washington, DC, USA, 2014.

45. Jepsen, S.; Schweitzer, D.F.; Young, B.; Sears, N.; Ormes, M.; Black, S.H. Conservation Status and Ecology of the Monarch Butterfly in the United States; U.S. Forest Service: Washington, DC, USA, 2016. 
46. U.S. Fish and Wildlife Service Status of the Monarch Butterfly. Available online: https://www.fws.gov/ savethemonarch/SSA.html (accessed on 5 January 2018).

47. Landis, T.D. Monarch waystations: Propagating native plants to create travel corridors for migrating monarch butterflies. Native Plants J. 2014, 15, 5-16. [CrossRef]

48. Thogmartin, W.E.; López-Hoffman, L.; Rohweder, J.; Diffendorfer, J.; Drum, R.; Semmens, D.; Black, S.; Caldwell, I.; Cotter, D.; Drobney, P.; et al. Restoring monarch butterfly habitat in the Midwestern US: 'All hands on deck'. Environ. Res. Lett. 2017, 12, 074005. [CrossRef]

49. Pleasants, J. Milkweed restoration in the Midwest for monarch butterfly recovery: Estimates of milkweeds lost, milkweeds remaining and milkweeds that must be added to increase the monarch population. Insect Conserv. Divers. 2017, 10, 42-53. [CrossRef]

50. Oberhauser, K.; Wiederholt, R.; Diffendorfer, J.E.; Semmens, D.; Ries, L.; Thogmartin, W.E.; Lopez-Hoffman, L.; Semmens, B. A trans-national monarch butterfly population model and implications for regional conservation priorities. Ecol. Entomol. 2017, 42, 51-60. [CrossRef]

51. Malcolm, S.B. Anthropogenic impacts on mortality and population viability of the monarch butterfly. Annu. Rev. Entomol. 2018, 63, 277-302. [CrossRef] [PubMed]

52. Pyle, R.M. Conservation of Lepidoptera in the United States. Biol. Conserv. 1976, 9, 55-75. [CrossRef]

53. Lewandowski, E.J.; Oberhauser, K.S. Contributions of citizen scientists and habitat volunteers to monarch butterfly conservation. Hum. Dimens. Wildl. 2017, 22, 55-70. [CrossRef]

54. Diffendorfer, J.E.; Loomis, J.B.; Ries, L.; Oberhauser, K.; Lopez-Hoffman, L.; Semmens, D.; Semmens, B.; Butterfield, B.; Bagstad, K.; Goldstein, J.; et al. National valuation of monarch butterflies indicates an untapped potential for incentive-based conservation. Conserv. Lett. 2014, 7, 253-262. [CrossRef]

55. Penn, J.M.; Penn, H.J.; Potter, M.F.; Hu, W. Bed bugs and hotels: Traveler insights and implications for the industry. Am. Entomol. 2017, 63, 79-88. [CrossRef]

56. Garcia, X.; Llausàs, A.; Ribas, A. Landscaping patterns and sociodemographic profiles in suburban areas: Implications for water conservation along the Mediterranean coast. Urban Water J. 2014, 11, 31-41. [CrossRef]

57. Kühn, E.; Feldmann, R.; Harpke, A.; Hirneisen, N.; Musche, M.; Leopold, P.; Settele, J. Getting the public involved in butterfly conservation: Lessons learned from a new monitoring scheme in Germany. Isr. J. Ecol. Evol. 2008, 54, 89-103. [CrossRef]

58. Groves, R.M.; Presser, S.; Dipko, S. The role of topic interest in survey participation decisions. Public Opin. Q. 2004, 68, 2-31. [CrossRef]

59. Wiernik, B.; Ones, D.S.; Dilchert, S. Age and environmental sustainability: A meta-analysis. J. Manag. Psychol. 2013, 28, 826-856. [CrossRef]

60. Dupont, D.P. Do children matter? An examination of gender differences in environmental valuation. Ecol. Econ. 2004, 49, 273-286. [CrossRef]

61. Torgler, B.; Garcia-Valiñas, M.A.; Macintyre, A. Differences in Preferences towards the Environment: The Impact of a Gender, Age and Parental Effec; FEEM Working Paper No. 18.2008; Center for Research in Economics, Management and the Arts: Basel, Switzerland, 2008. [CrossRef]

62. Guiney, M.; Oberhauser, K. Insects as flagship conservation species. Terr. Arthropod Rev. 2009, 1, 111-123. [CrossRef]

63. Chapman, R.G.; Staelin, R. Exploiting rank ordered choice set data within the stochastic utility model. J. Mark. Res. 1982, 19, 288-301. [CrossRef]

64. Sloan, S. KY Has a Wide Variety of Specialty License Plates. KY Herald Leader, 15 April 2013.

65. Mcinerney, C.; Bird, N.; Nucci, M. The flow of scientific knowledge from lab to the lay public: The case of genetically modified food. Sci. Commun. 2004, 26, 44-74. [CrossRef]

66. Marcotty, J. Calling All Milkweed: Federal Pollinator Plan Needs a Billion Plants for Monarch Butterflies. Star Trib. 2015. Available online: http://www.startribune.com/calling-all-milkweed-federal-pollinatorplan-needs-a-billion-plants-for-monarchs/306383591/ (accessed on 13 March 2018).

67. Higgins, A. Are Our Gardens the Monarch Butterfly Sanctuaries We Think They Are? The Washington Post, 19 July 2017.

68. Trezza, J. Monarch Butterfly Migration Was Off This Year and Researchers Are Worried. The Washington Post, 24 January 2018. 
69. Frick, J.; Kaiser, F.G.; Wilson, M. Environmental knowledge and conservation behavior: Exploring prevalence and structure in a representative sample. Personal. Individ. Differ. 2004, 37, 1597-1613. [CrossRef]

70. Ballantyne, R.; Packer, J.; Hughes, K.; Dierking, L. Conservation learning in wildlife tourism settings: Lessons from research in zoos and aquariums. Environ. Educ. Res. 2007, 13, 367-383. [CrossRef]

71. Leiserowitz, A. Climate change risk perception and policy preferences: The role of affect, imagery, and values. Clim. Chang. 2006, 77, 45-72. [CrossRef]

72. Campbell, L.M.; Smith, C. What makes them pay? Values of volunteer tourists working for sea turtle conservation. Environ. Manag. 2006, 38, 84-98. [CrossRef] [PubMed]

73. Dalton, R.J. The greening of the globe? Cross-national levels of environmental group membership. Environ. Politics 2005, 14, 441-459. [CrossRef]

74. Leonidou, L.C.; Coudounaris, D.N.; Kvasova, O.; Christodoulides, P. Drivers and outcomes of green tourist attitudes and behavior: Sociodemographic moderating effects. Psychol. Mark. 2015, 32, 635-650. [CrossRef]

75. Casaló, L.V.; Escario, J.-J. Heterogeneity in the association between environmental attitudes and pro-environmental behavior: A multilevel regression approach. J. Clean. Prod. 2018, 175, 155-163. [CrossRef]

76. Schultz, P.W.; Gouveia, V.V.; Cameron, L.D.; Tankha, G.; Schmuck, P.; Franěk, M. Values and their relationship to environmental concern and conservation behavior. J. Cross-Cult. Psychol. 2005, 36, 457-475. [CrossRef]

77. Dietz, T.; Stern, P.C.; Guagnano, G.A. Social structural and social psychological bases of environmental concern. Environ. Behav. 1998, 30, 450-471. [CrossRef]

78. Franzen, A.; Meyer, R. Environmental attitudes in cross-national perspective: A multilevel analysis of the ISSP 1993 and 2000. Eur. Sociol. Rev. 2010, 26, 219-234. [CrossRef]

79. Schultz, P.W.; Oskamp, S.; Mainieri, T. Who recycles and when? A review of personal and situational factors. J. Environ. Psychol. 1995, 15, 105-121. [CrossRef]

80. Schahn, J.; Holzer, E. Studies of individual environmental concern: The role of knowledge, gender, and background variables. Environ. Behav. 1990, 22, 767-786. [CrossRef]

81. Czech, B.; Devers, P.K.; Krausman, P.R. The relationship of gender to species conservation attitudes. Wildl. Soc. Bull. 1973-2006 2001, 29, 187-194.

82. Dietz, T.; Kalof, L.; Stern, P.C. Gender, values, and environmentalism. Soc. Sci. Q. 2002, 83, 353-364. [CrossRef]

83. Tindall, D.B.; Davies, S.; Mauboules, C. Activism and conservation behavior in an environmental movement: The contradictory effects of gender. Soc. Nat. Resour. 2003, 16, 909-932. [CrossRef]

84. Yates, A.; Luo, Y.; Mobley, C.; Shealy, E. Changes in public and private environmentally responsible behaviors by gender: Findings from the 1994 and 2010 general social survey. Sociol. Inq. 2015, 85, 503-531. [CrossRef]

85. Strapko, N.; Hempel, L.; MacIlroy, K.; Smith, K. Gender differences in environmental concern: Reevaluating gender socialization. Soc. Nat. Resour. 2016, 29, 1015-1031. [CrossRef]

86. Fien, J.; Scott, W.; Tilbury, D. Education and conservation: Lessons from an evaluation. Environ. Educ. Res. 2001, 7, 379-395. [CrossRef]

87. Schaefer, J.A.; Beier, P. Going public: Scientific advocacy and North American wildlife conservation. Int. J. Environ. Stud. 2013, 70, 429-437. [CrossRef]

88. Arcury, T. Environmental attitude and environmental knowledge. Hum. Organ. 1990, 49, 300-304. [CrossRef]

89. Zeppel, H. Education and conservation benefits of marine wildlife tours: Developing free-choice learning experiences. J. Environ. Educ. 2008, 39, 3-18. [CrossRef]

90. Richter, T.; Rendigs, A.; Maminirina, C.P. Conservation messages in speech bubbles-evaluation of an environmental education comic distributed in elementary schools in Madagascar. Sustainability 2015, 7, 8855-8880. [CrossRef]

91. Knight, R.L. Private lands: The neglected geography. Conserv. Biol. 1999, 13, 223-224.

92. Jacobson, S.K.; Sieving, K.E.; Jones, G.A.; Van Doorn, A. Assessment of farmer attitudes and behavioral intentions toward bird conservation on organic and conventional Florida farms. Conserv. Biol. 2003, 17, 595-606. [CrossRef]

93. Gould, B.W.; Saupe, W.E.; Klemme, R.M. Conservation tillage: The role of farm and operator characteristics and the perception of soil erosion. Land Econ. 1989, 65, 167-182. [CrossRef]

94. Featherstone, A.M.; Goodwin, B.K. Factors influencing a farmer's decision to invest in long-term conservation improvements. Land Econ. 1993, 69, 67-81. [CrossRef] 
95. Traoré, N.; Landry, R.; Amara, N. On-farm adoption of conservation practices: The role of farm and farmer characteristics, perceptions, and health hazards. Land Econ. 1998, 74, 114-127. [CrossRef]

96. Stern, P.C.; Dietz, T.; Abel, T.D.; Guagnano, G.A.; Kalof, L. A value-belief-norm theory of support for social movements: The case of environmentalism. Hum. Ecol. Rev. 1999, 6, 81-97. 